\title{
Reflection on Language, Culture and Translation and Culture as a Challenge for Translation Process
}

\author{
PhD. Candidate Morena Braçaj
}

Lecturer "Aleksander Moisiu" University, Albania

Email address: morenacitozi@yahoo.com

\section{Doi:10.5901/jesr.2014.v4n4p332}

\begin{abstract}
The study of language, culture and translation and the relationship between them are crucial issues because of the importance of human communication in the world. Language is viewed as the main factor that links different cultures of different nations and a way of expressing feelings, thoughts and ideas that people try to convey. Language and culture are closely related to each other. Language is considered as a part of culture of a particular community and the main way by which the members of a society communicate with each other. The variety of languages with different cultures and necessity of communications in human life caused translation to be a very effective factor in communicating, exchanging cultures, and knowledge. Thus, it seems that language and culture are closely related and it is essential to consider both in the process of translation. Therefore, this paper aims to focus on concept of culture from different viewpoints in translation studies and to offer an analysis of researchers' views of the interaction between culture and language and also between culture and translation. Furthermore, we know that translation plays an important role of crossing through different cultures and communication. Therefore, it is said that translation is one of the essential, fundamental, and adequate ways in transferring culture. However, the translator encounter many different types of challenges because in order to translate properly, a good translator should have knowledge not only about linguistic components but also about cultural elements, views, customs and tradition in order to take into consideration the chronological orders, historical and religious background of the source text. Lastly, what is the most essential point is the transmission of the same message as the source text attempted to and avoid adding irrelevant words into language used by people. All these factors should be considered during the translating process and will be discussed in this paper.
\end{abstract}

Keywords: Language, culture, translation process, communication.

\section{Introduction}

Many different theorists have given different definitions on language, culture and translation. If we focus on the language, it can be said that in humankind history language has proved to be the best tool with which human beings could express most of their feelings, needs, beliefs, experiences and attitudes, and at the same time, transmitting knowledge and traditions from one generation to another. The problem, however, is that not all people share the same language and culture. At this point the necessary and immediate intervention of translation and translators is felt. Studying on language, culture and translation and the relationship between them are valuable issues due to the importance of human communication in the world. The variety of languages with different cultures and necessity of communications in human life caused translation to be a very effective factor in communicating, exchanging cultures, and knowledge. Thus, it seems that language and culture are closely related and it is essential to consider both in the process of translation. Although there might be is no specific frame and force on how a translation must be done, all translators who transfer natural meaning based on the cultural and religious norms of their society, encounter some limitations through translation. In this study we discuss the translation through transferring cultures among languages and also define that translation has an important role in globalization of cultures especially pop culture leading to expanding ethnic habits and customs, or religious values. As languages and culture are complimentary of each other, and cultural features of every region is different, translators not only should concentrate on how to convey the same meaning, but also attempt to show the dissimilarities between two cultural perspectives. As Kramsch (1998) states language is a system of signs that is seen as having itself a cultural value. Speakers identify themselves and others through their use of language; they view their language as a symbol of their social identity. The prohibition of its use is often perceived by its speakers as a rejection of their social group and their culture. Thus, we can say that language symbolizes cultural reality. On the interaction between translation and culture as House (2009) believestranslation is not only a linguistic act, but it is also a cultural one; i.e., an act of communication across cultures. Translation always involves both language and culture simply because the two cannot really be separated. Language is culturally embedded. It both expresses and shapes cultural reality, and the meanings of linguistic items, be they words or larger segments of text, and it can only be understood when 
considered together with the cultural context in which these linguistic items are used. Cultural elements existing in every society determine how individuals go about the process of comprehending and interpreting written/spoken texts. In other words, texts are the manifestation of the socio cultural norms of a particular society within which the people of the society interpret their own behaviors and those of others. The culture specificity of texts means that texts cannot be directly translated from a SL to a TL and this fact poses problem to translators when they encounters cultural items in the text they are to translate. The translation of literary texts is the most difficult one because it contains so much cultural elements. Therefore, literary-text translators should be familiar with both the source and the target cultures. Further they should exploit the most effective strategies at their disposal so that- as Nida believes- the translation of cultural items from the SL into the TL has the same effect on the TL readers as it does on the SL readers (As cited in Munday, 2001, p. 42).

\section{Relation between Language and Culture}

Firstly, it is very important to present some different definitions of culture by different linguists. One of the oldest and most quoted definitions of culture was formulated by the English anthropologist Edward Burnett Tylor in his classic book Primitive Culture in 1871. "Culture is that complex whole which includes knowledge, belief, art, morals, law, customs and any other capabilities and habits acquired by man as a member of society".(As quoted in Katan 1999, p.16). According to Sapir (1921), "language is a purely human and non-instinctive method of communicating ideas, emotions and desire by means of voluntarily produced symbols." Language is a part of culture and a part of human behavior. It is often held that the function of language is to express thought and to communicate information. Language also fulfills many other tasks such as greeting people, conducting religious service, etc. Larson (1984, p. 430) defines culture as "a complex of beliefs, attitudes, values, and rules which a group of people share". Another famous linguist, Newmark, gives a definition of culture as follows: "The way of life and its manifestations that are peculiar to a community that uses a particular language as its means of expression" (1988, p. 94). Shezai Rrokaj defines culture as: "the whole of codified completed and interpreted behaviors by members of social community in communication situations". There are many different thoughts given by different theorists on the relationship between language and culture. Although the majority confirms the language and culture as concepts indispensible, some hypotheses insist on the irrelevancy of these two concepts. In Katan's (1999) opinion, Malinowski was one of the first anthropologists to realize that language could only be understood with reference to culture. In 1923 he coined the term 'context of situation' and noted that a language could only be fully understood, i.e. have meaning, when this two contexts (situation and culture) were implicitly or explicitly clear to the interlocutors and hearers (Katan 1999, p. 72). Bennet $(1998$, p. 3) has somehow the same view. He explains that the "fundamental premise of 'the intercultural communication approach 'is that 'cultures are different in their languages, behavior patterns', and values". Kramsch's belief on the relationship between language and culture is worthwhile. She believes that: Language is a system of signs that is seen as having itself a cultural value. Speakers identify themselves and others through their use of language: they view their language as a symbol of their social identity. The prohibition of its use is often perceived by its speakers as a rejection of their social group and their culture. Thus we can say that language symbolizes cultural reality (Kramsch, 1998, p. 3). Sapir (1929, p. 214), like Malinowski, was convinced that language could only be interpreted within a culture. However, he went further, suggesting that "no two languages are ever sufficiently similar to be considered as representing the same reality. Sapir introduces his essay on 'Language Race and Culture' (1949, p. 207) with these words: "Language has a setting ... language does not exist apart from culture" (As quoted in Katan, 1999, p. 73). On the contrary, Newmark (1988, p. 95) does not regard language as a component or feature of culture. He believes that "if it were so, translation would be impossible". Hongwei (1999) believes in language as a portrait of culture. He says that "language mirrors other parts of culture, supports them, spreads them and helps to develop others" (p.121). This special feature of language distinguishes it from all other facets of culture and makes it crucially important for the transfer of culture. It is no exaggeration to say that, as Hongwei believes too, "language is the life-blood of culture and that culture is the track along which language forms and develops" (p. 121). The formation and development of all aspects of a culture are closely related to one another, and language is no exception. A careful study of the meanings of words and how these change demonstrate how material culture, institutional culture and mental culture influence the formation and development of language (Hongwei, 1999, p. 123). Although it is said that there is no two definitions of culture that are identical, all definitions have got elements that are repeated similarly in them. For example, elements of belief and value, even if not stated explicitly, have been implied in majority of them.

Culture, argued by many anthropologists, most notably Clifford Geertz, is a symbolic meaning system. It is semiotic system in which symbols function to communicate meaning from one mind to another. Cultural symbols encode a connection between a signifying form and a signaled meaning. From the point of view of contemporary cultural 
anthropologists, culture is characterized by the following four basic features:

1) Culture is a kind of social inheritance instead of biological heritage;

2) Culture is shared by the whole community, not belonging to any particular individual;

3) Culture is a symbolic meaning system in which language is one of the most important ones;

4) Culture is a unified system, the integral parts of which are closely related to one another.

Various definitions on culture are given by scholars from different points of view. Some treated culture superficially as a set of specific artifacts, man-made environments, patterns of social organization and overt forms of behavior. Others treated culture in a more abstract way as the shared knowledge of members of social communities like world views, value orientations, norms, manners, customs, preferred styles of thinking and arguing, etc. Being taken as "socially acquired knowledge" (Hudson, 1980: 74), culture is classified by some scholars into cultural knowledge information and cultural communication information. The former refers to the factual information which does not exert a direct influence on the cross-cultural communication, including a nation's history, geography and so on. The latter points to the socio-pragmatic rules in daily communication which entail not only ways of greeting, thanking, apologizing and addressing, but also attention to taboos, euphemisms, modesty and polite formula in use, etc.

\section{Relation between Culture and Translation}

It is viewed by many theorists that both translation and culture move in the same path in parallel to each other, based on the fact that translation process means a transferation not only between two languages but also between two cultures because both original language and target language are rooted in communicative situations in their respective cultures. On the interaction between translation and culture, House believes that: "Translation is not only a linguistic act; it is also a cultural one, an act of communication across cultures. Translation always involves both language and culture simply because the two cannot really be separated. Language is culturally embedded: it both expresses and shapes cultural reality, and the meanings of linguistic items, be they words or larger segments of text, can only be understood when considered together with the cultural context in which these linguistic items are used" $(2009, p$. 11). She then sum up with this statement that "in the process of translation, therefore, not only the two languages but also the two cultures come into contact. In this sense, it can be said that translating is a form of intercultural communication" (House, 2009, p. 12). Anyone who has ever attempted to translate a text knows that knowledge of the languages alone does not guarantee success. Peter Newmark (1995, p. 79) notes sharply but aptly that: "any old fool can learn a language [...] but it takes an intelligent person to become a translator". In Venuti's view, the viability of a translation is established by its relationship to the cultural and social conditions under which the translation is produced and read. So far what is clearly common in the majority of translation scholar is being not ignored of the cultural consideration in translation process. According to Nida and Taber, cultural translation is "a translation in which the content of the message is changed to conform to the receptor culture in some way, and/or in which information is introduced which is not linguistically implicit in the original" (Nida and Taber, 1982, p.199). Regarding the close relationship between translation and culture "Snell-Hornby (1988,p. 41) has pointed out, the translatability of a text depends on the extent to which the text is 'embedded in its own specific culture' and also on how far apart, with regard to time and place, the ST and TT receivers are" (As quoted in Leppihalme, 1997, p. 4). As the final statement on the relationship between translation and culture, Leppihalme (1997) states that: Culturally oriented translation studies, then, do not see the source text (ST) and the target text (TT) simply as samples of linguistic material. The texts occur in a given situation in a given culture in the world, and each has a specific function and an audience of its own.

Munday (2001, p. 127) reports that "Bassnett and lefevere go beyond language and focus on the interaction between translation and culture, on the way which culture impacts and constrains translation and on 'the larger issues of context, history and convention"'. He adds that "the move from translation as text to translation as culture and politics is what Mary Snell-Hornby terms 'the cultural turn"(p. 127).Venuti (1995, p.305) notes that: Translation is a process that involves looking for similarities between language and culture -particularly similar messages and formal techniques -but it does this because it is constantly confronting dissimilarities. It can never and should never aim to remove these dissimilarities entirely. A translated text should be the site at which a different culture emerges, where a reader gets a glimpse of a cultural other and resistency (As quoted in Rubel \& Rosman, 2003, p.11). Translation is, in fact, a converting process. Theoretically, a good translation should give its reader the same conception as what a native reader gets from the original. Nida remarked that how to determine a good translation is the response of the receptor to the translated message, and this message must then be compared with the way in which the original receptors presumably reacted to the message when it was given in its original setting. Jakobson held the view that translation does not just mean the change of symbols into another language, but it is a process of information substitution. The task of a translator is to 
translate the information he receives into symbols which he will send out. Catford explained that in translation there is no meaning equivalence, but just the signifier equivalence. Because of the differences between the original language and the target language, there exists the translation equivalence limitedness. This limitedness is not only manifested in the meaning of words, grammatical features, but also manifested in cultural differences more seriously. Toury (2000) states that "translation is a kind of activity which inevitably involves at least two languages and two cultural traditions, i.e., at least two sets of norm-systems on each level" (p. 207). Also Armstrong (2005, p, 3) is among those who believed that just a bilingual and bicultural translator is able to carry out a complete translation.

\section{Culture as a Great Challenge for Translation}

Translation plays a vital role in making a culture universal and general. It acts as a bridge to communicate all kinds of languages specially those similar to each other considering their linguistic features and cultural customs in all parts of the world. So it links all units of the world in the global network. Moreover translation presumes the existence of boundaries between different cultures and the translator most probably is aware of these boundaries and the inevitability of crossing them. Without cultural similarities and universalities, there is no way for people of different cultures to communicate with each other and translation will be impossible. When speaking of two languages which are to be translated equivalently, translators must convey the same referential, pragmatic and interlinked meanings. However, due to differences between two cultures, semantic equivalence is limited. The purpose and characteristics of translation are to promote understanding among different countries and nations. Eugene Nida, a famous translation theorist, defined translation as: "translation consists in reproducing the receptor language the closest natural equivalent of the source language, first in terms of meaning and secondly in terms of style". However, to reproduce "the closest natural equivalent" in the target language is more or less influenced by the cultural differences. Because of the differences in histories, geographic locations, local customs and religious beliefs, etc., there are some translation obstacles which prevent people from understanding each other properly. So, translation not only involves translator's or interpreter's linguistic competence, but also should be continuously in contact with those cultures. In this sense, translation means more that merely translating the words, sentences or articles from the source language into the target language. It means also to transfer between cultures.

Difficulties arising out of differences of cultures constitute the most serious problems for translators and have produced the most far-reaching misunderstanding among readers. Culture itself has its own limitation in transferring the source text into target text. Each society or group of people based on their historical background, local situations, and religion with their specific language, construct their own culture which is respected, performed and accepted along with its limitations. Limitation in translation is one of the specific features of culture, not necessarily imposed from outside world.

Culture has a great impact on translation process. It is considered to be one of the greatest challenges for translation, as the translator should be aware of cultural elements of original text in order to transmit the message in the target language as natural as in the original one, so that the reader can experience the same feeling that the author of the original language tends to convey to the readers. Many different definitions of translation have been given by theorists, relating the language with translation. However, in the last two decade, especially in 1980s, the role of translation has shifted in a different direction, giving priority to cultural problems and the difficulties that the translators encounter during the translation process. Therefore, in the recent years, translation is oriented towards cultural approaches than linguistics ones. Snell-Hornby (1988: 43) argues that "translation approaches are oriented to the function of the target text (prospective translation), than oriented to prescription of the source text (retrospective translation). Furthermore, she adds that "the text is viewed as a part of the world and not as an isolated part of the language". Translation theorists have been aware of the problems upon cultural knowledge and cultural differences at least since ancient Rome. Cultural knowledge and cultural differences have been a major focus of translator training and translation theory for as long as either has been in existence. The main concern has traditionally been with words and phrases that are so heavily and exclusively grounded in one culture that they are almost impossible to translate into the terms - verbal or otherwise - of another. Long debate have been held over when to paraphrase, when to use the nearest local equivalent, when to coin a new word by translating literally, and when to transcribe. All these "untranslatable" cultural-bound words and phrases continued to fascinate translators and translation theorists.

In 1990, Susan Bassnett and André Lefevere edited a collection of essays entitled Translation, History and Culture. They co-wrote the introductory essay to the volume, intending it as a kind of manifesto of what we saw as a major change of emphasis in translation studies. We were trying to argue that the study of the practice of translation had moved on from its formalist phase and was beginning to consider broader issues of context, history and convention:

Now, the questions have changed. The object of study has been redefined; what is studied is the text embedded in 
its network of both source and target cultural signs and in this way Translation Studies has been able both to utilize the linguistic approach and to move out beyond it. (Bassnett \& Lefevere, 1990). Therefore, this shift of emphasis is called 'the cultural turn' in translation studies. Apart from that, there was a shift in the role of translators, who changed from interlinguist mediators to cultural ones, whose focus was primary on the introduction of cultural differences rather than on grammar and lexis. Since 1990, the turn has extended to incorporate a whole range of approaches from cultural studies and is a true indicator of the interdisciplinary nature of contemporary translation studies. As the result of this so called Cultural Turn, cultural studies has taken an increasingly keen interest in translation. One consequence of this has been bringing together scholars from different disciplines. It is here important to mention that these cultural theorists have kept their own ideology and agendas that drive their own criticism. These cultural approaches have widened the horizons of translation studies with new insights but at the same there has been a strong element of conflict among them. It is good to mention that the existence of such differences of perspectives is inevitable. Lawrence Venuti points out that translation, wherever, whenever and however it takes place, is always to some extent circumscribed: Every step in the translation process from the selection of foreign texts to the implementation of translation strategies to the editing, reviewing and reading of translations is mediated by the diverse cultural values that circulate in the target language, always in some hierarchical order. (Venuti, 1995). Translation is therefore always enmeshed in a set of power relations that exist in both the source and target contexts. The problems of decoding a text for a translator involve so much more than language, despite the fact that the basis of any written text is its language. Moreover, the importance of understanding what happens in the translation process lies at the heart of our understanding of the world we inhabit. And if translation studies have been increasingly concerned with the relationship between individual texts and the wider cultural system within which those texts are produced and read, it is therefore not surprising that within cultural studies, and in post-colonial theory in particular, translation is increasingly being seen both as actual practice and as metaphor. (Bassnett \& Lefevere, 1998).

\subsection{Mona Baker}

\section{Conclusion}

Language is rooted in culture and culture is reflected and passed on by language from one generation to the next. From this, one can see that learning a new language involves the learning of a new culture. Knowledge, beliefs, perspectives transfer through language and culture. Culture links the past, present and future together. The significance of it has been a matter of debate as long as there has been a need for translation. translation is not just a literal producing of a work from one language to another, but is also an adaptation of one culture's values and biases into another Translation seems to be the only possible way to "unite" all cultures in order to create cultural network, cultural globalization. Moreover, it can be said that on the interaction between translation and culture as House (2009) believes translation is not only a linguistic act, but it is also a cultural one; i.e., an act of communication across cultures. Translation always involves both language and culture simply because the two cannot really be separated. Language is culturally embedded. It both expresses and shapes cultural reality, and the meanings of linguistic items, be they words or larger segments of text, and it can only be understood when considered together with the cultural context in which these linguistic items are used. Translation is not just a literal recasting of a work from one language to another, but is also an adaptation of one culture's values and biases into another. Moreover, translation seems to be the only possible way to "unite" all cultures in order to create cultural network, cultural globalization.

\section{References}

Bell, R.T. (1991). Translation and translating. London: Longman.

Bennett, M. J. (1998). Intercultural communication: a current perspective. In M. J. Bennett (Ed.), Basic concepts of intercultural communication: Selected reading (pp. 1-34).Yarmouth, ME: Intercultural Press Inc.

Larsen, M. (1984). Meaning-based translation:A guide to cross-language equivalence (2nd ed).

Newmark, P. (1981). Approaches to translation. Oxford:Pergamon Press.

Newmark, P. (1988). A textbook of translation. Hamel Hempstead:Prentice Hall

Newmark. P.(1988). A Textbook of Translation. New York: Prentice Hall. 1988, p. 94.

Robinson, G. (1988). Crosscultural understanding. Hemel Hempstead, Hertfordshire:Prentice Hall International.

Sapir, E. (1929). The status of Linguistics as a Science. Language, 5, 207-214.

Sapir, E. (1949). Culture, language and personality. Los Angeles: University of California Press.

E. A. Nida, CR Ward. From One Language to Another: Functional Equivalence in Bible Translation. Tennessee: Thomas Nelson 
Publishers. 1981.

D. Hymes. (ed). Language in Culture and Society. A Reader in Linguistics and Anthropology. New York: Harper \& Row. 2000.

L.M. Larson. Meaning-Based Translation.University Press of America. 1998.

Hongwei, C. (1999). Cultural difference and translation. Translations' Journal,44, 121-132.

House, J. (2009). Translation. Oxford and New York, Oxford university press.

Katan, D. (2009). Translation as intercultural communication. In J. Munday (Ed.),

The Routledge companion to translation studies (pp. 74-92). Abingdon: Routledge.

Katan, D .(1999). Translating cultures an introduction for translators, interpreters and mediators. Manchester:St Jerome

Venuti, L. (1995). The translator's invisibility. A history of translation. London and New York: Routledge.

Venuti, L. (Ed) (2004). The translation studies reader. London and New York: Routledge

Snell-Hornby, M. (1988). Translation studies: An integrated approach. Amsterdam: John

Benjamins.

Leppihalme, R. (1997). Culture bumps .Clevedon: Multilingul Matters.

Munday, J. (2001). Introducing translation studies: Theories and application. New York: Routledge.

Nida, E.A.. \&Taber, C. R. (1969) The theory and practice of translation. Leiden: E.J. Brill.

Rrokaj, Shezai. (2012). Botimi Arbëria, Tiranë, pp 62.

Toury, G. (1978/2004). 'The nature and role of norms in translation', in L. Venuti (Ed.), (2000) The translation studies reader (pp. 205218). London and New York: Routledge.

Kramsch, C. (1998). Language and culture. Oxford:Oxford University Press. nslation studies reader (pp. 205-218). London and New York: Routledge.

W.H. Goodenough. Cultural Anthropology and Linguistics. In: D. Hymes (Ed.), Language in Culture and Society. New York: Harper \& Row. 1954, pp. 36-39 